\title{
Religiosity of Malays Living in Malaysian Rural Areas: An Analytical Survey
}

\author{
ABDUL RASHID MOTEN* \& SAODAH WOK ${ }^{1}$
}

\begin{abstract}
Religion affects an individual's perception and the way in which people behave. The Malays in Malaysia observe religious rites and rituals and portray Islamic values in their behavior. Based upon a sample survey, this study examines respondents' belief in the deity, the frequency and intensity of their involvement in religious rites and rituals, and their devotion to religious ceremonies. It is hypothesized that a person with a higher level of religiosity is more likely to align his/her behavior in compliance with religious belief and practices. This study finds that the Malays are polite in their behavior to their parents, try to help others, refrain from taking interests on loans to friends, and the like. Islam seems to influence all aspects of the behavior of the Malays in Malaysia. Most of them would abide by most of the dictates of their religion in their dealings with others. Religiosity is not significantly related to age, education, gender, and marital status. However, the rural population consistently scores high on all measures of religiosity.
\end{abstract}

Keywords: Islam in Malaysia, Malays, religiosity, religious behavior, rural areas

Religion is usually subsumed under the all-encompassing concept of culture, which according to Hofstede (1980), includes the norms, values, and beliefs shared by members of a particular group or community in a particular area or geographic location. Religion is a critical element in the cultural environment. It affects an individual's perception and the way in which people behave (Sadler 1970). It directly affects individual behavior through the rules and taboos it inspires, and indirectly through classification of all phenomena, development of a code of conduct, and the establishment of priorities among these codes (Sood \& Nasu 1995). Thus, scholars point out the five obligatory daily prayers as training for the way people should behave in the society. According to the Quran, prayer helps in pursuing virtuous acts in the society while keeping people away from committing sins. Likewise, Islam has categorized things and acts that are halal (permissible), haram (prohibited), and makruh (hated). Muslims are encouraged to engage whole-heartedly in halal activities; shun prohibited foods, behaviors, and transactions; and stay away as much as possible from all things declared makruh. Another basic element of Islam is akhlaq (moral and values), which provides a framework that shapes the moral and ethical behaviors of Muslims in the conduct of all aspects of their lives (Saeed et al., 2001). The Quran and Sunnah (sayings and doings) of Prophet Muhammad provide believers with a stable and flawless set of values to live by.

Scholars have tried to measure the level of religiosity of individuals. As with all other concepts, scholars disagree on a uniformly applicable definition of religiosity. Caird (1987) looks at cognitive (focusing on religious attitudes or beliefs), behavioral (counting attendance in

\footnotetext{
${ }^{1}$ Abdul Rashid Moten*(corresponding author), Ph.D., emeritus professor and guest writer, International Islamic University (IIUM), 53100 Jalan Gombak, KUALA LUMPUR, Malaysia, email: rashidmoten@gmail.com; Saodah Wok, Ph.D., professor at the Department of Communication, International Islamic University Malaysia (IIUM), 53100 Jalan Gombak, KUALA LUMPUR, Malaysia, email: wsaodah@iium.edu.my.
} 
religious gatherings or private prayers), and experiential (querying mystical experiences) aspects. Mookherjee (1993) measures religiosity by church membership and the frequency of church attendance, the frequency of prayers, reading religious texts, and a cumulative score of devotional intensity. He argues that measuring religiosity is crucial as it may influence an individual's behavior. He advances the hypothesis that a high level of religiosity is likely to make an individual more dogmatic and more conservative than those who score low on religiosity. We are, therefore, likely to meet a "highly" religious person (or the devout) who aligns her/his behavior in compliance with religiously sanctioned practices. Those strongly committed to religion are both attitudinally and behaviorally able to make choices consistent with a moral conscience. In the language of the Quran, these people will enjoin virtue and forbid vice. These are the people who will attain salvation in this world and the hereafter.

Religiosity, according to many scholars, is declining with the triumphant march of modernization and globalization. Bruce (2002) and Lechner (1996) use empirical evidence to substantiate their argument for the decline in religiosity. They provide evidence that in the West, church attendance and the belief in church religion have declined.

There has been an increase in religiosity despite institutional differentiation. A clear distinction between the term religiosity whether it is in an organized or individualized form and whether it is in a traditional or untraditional form. For instance, the increase in religiosity can be due to an increase in the number of modern churches instead of traditional churches. Modern churches have significantly less liturgical elements and are more accommodative to the secularising world as compared to traditional churches (Bruce 1998). They have more engagement in contemporary worship, which involves charismatic speeches, modern music, and even dances rather than merely sermons, rites, and anaphora.

One question that is important for religiosity is to examine the motives of being and doing things that are considered religious. It is argued that the ideal motive for attendance in religious gatherings is salvation (Azzi \& Enrenberg 1975). However, there are many non-salvation motives such as social, financial, traditional, and status-related. The social motive, for example, is the friendly communal interaction and exchange of ideas with fellow congregants (Monaghan 1967). Other non-salvation motives include tradition, social belonging, and status. In the Scandinavian countries, religion is considered a mere tradition where the religious institution is needed more for burials than life, which partly explains the high rates of religious belonging (Demerath 2000), although these countries are among the most secular in the world with low rates of attendance and belief.

Scholars have also resorted to classifying religiosity. Among the frequently used classifications for types of religiosity are extrinsic and intrinsic religiousness (Allport \& Ross 1967). Briefly, extrinsic religiousness refers to religion that is used to achieve something else (e.g. higher status, social conformity, financial benefits) while intrinsic religiousness refers to religion that is lived, which means that one who has intrinsic religiousness believes, follows, and does not expect any non-religious or more specifically, non-transcendent benefits from being religious.

In addition to the duality between extrinsic and intrinsic religiosity, there is a frequently used term in the study of religion-modern religiosity, which is different from traditional religiosity. There are many ways to describe modern religiosity. Kliever (1979) describes modern religiosity as a religious belief that takes into account individual autonomy, rational criticism, and political freedom, which means that one is no longer constrained by any authority on how and what to believe in.

Article 160(2) of the Malaysian Constitution specifies that a Malay is a "person who professes the Muslim religion, habitually speaks the Malay language and conforms to the Malay custom". Given this definition, it is expected that the Malays in Malaysia are religious, observant of religious rites and rituals, and portray Islamic values in their behavior. This chapter examines the level of respondents' religiosity by measuring their relationship with Allah, the importance that they place on prayer (salat), the performance of prayer (salat), recitation of Quran, practicing 
faith/worship ('ibadah), and moral behavior. Moreover, it explores and analyzes the institutions/persons whom they find solace in when facing problems and reference institutions/persons for searching religious information.

\section{Level of Religiosity}

The relationship between the cultural environment and ethical perceptions and behavior has been studied by many scholars in various fields (Hunt \& Vitel 1986; Srnka 2004). Culture, of which religion is the most important component, is seen to be associated with the micro-organizational behavior and the cognitive functioning of individuals.

Sadler (1970) points out that religion is a crucial element in the cultural environment and that religion affects the way people behave. Religion, argue Nasu and Sood (1995), affects individual behavior in two ways: first, religion prescribes the rules and taboos which the adherents abide by; and second, by classifying all phenomena into different categories, religion inspires its believers to shape their behaviors accordingly and to develop a code of conduct. For Muslims, the Holy Quran and the Sunnah of the Prophet provide a stable set of values, unlike other cultural factors that fluctuate upon variations in socio-economic and political conditions (Abdullah \& Siddique 1986).

Religiosity is a difficult construct to measure, and scholars have not agreed on a universal definition of religiosity. For example, Mookherjee (1993) defines religiosity in terms of variables such as church membership, the frequency of church attendance, the frequency of prayers, reading religious books, and the intensity of one's devotion to religious rites and rituals. Caird (1987) focuses on religious attitudes or beliefs, frequency and intensity of attending religious gatherings, and prayers besides the believer's mystical experiences.

Studies have found that religiosity is an important value in the cognitive structure of an individual and has a direct bearing on his/her behavior. Caird (1987) argues that a person taking his/her religion seriously is likely to be more dogmatic and more conservative than those who take it lightly or do not believe in it at all.

Religiosity in this study is measured by respondents' belief in the deity, the frequency and intensity of their involvement in religious rites and rituals, and their devotion to religious ceremonies. It is hypothesized that a person with a higher level of religiosity is more likely to align her behavior in compliance with religious belief and practices.

\section{Methodology}

This study is based upon data collected using a questionnaire from November 8-24, 2014. The survey, lasting between 20-30 minutes per respondent, was conducted by qualified and trained enumerators. A total of 800 respondents were selected using a stratified random sample. A total of 400 respondents came from rural families, reflecting a segment of the Malay farming community, the fishing community, typical Malay rubber smallholders, and small cash crop growers. Specifically, the sample included 100 respondents each from Pontian, Johor; Kampung Besut, Terengganu; Kampung Singkir, Kedah; and Manjoi, Perak. Another 400 respondents came from the urban Malay community in Kampung Baru, which is located in the center of Kuala Lumpur. Kampung Baru is an urban village, yet the traditional Malay identity is preserved, having similar Malay culture, traditions and values to the rural villages selected. The data were analyzed for the descriptive and inferential statistics. For this paper, only the descriptive statistics are used including frequency, percentage, mean, and standard deviation. 


\section{Results}

Relationship with Allah

To measure the level of religiosity, the respondents were asked about their relationship with Allah and the impact of such a relationship on their lives. As shown in Table 1, 11 statements were probing this aspect with the choice of either to agree or to disagree with these statements to a varying degree. An overwhelming majority of respondents ranging from $61.9 \%$ to $87.1 \%$ "agree strongly" with all the items. They are considered as possessing a high level of religiosity measured in terms of their relationship with Allah. What it means is that the majority of the respondents have full faith in Allah, and they believe that Allah cares about them and their lives. This belief has positive consequences in their lives. Because of this belief, they feel that their lives are meaningful, they have a purpose in life, and that Allah gives direction to fulfil their mission in life, so they are optimistic about their future. The future may be interpreted as a better life in this world as well as in the hereafter.

Table 1: Relationship with Allah

\begin{tabular}{|c|c|c|c|c|c|c|c|c|c|}
\hline \multirow[t]{2}{*}{ No. } & \multirow[t]{2}{*}{ Relationship with Allah } & \multicolumn{5}{|c|}{ Level of Agreement (\%)* } & \multirow[b]{2}{*}{$\mathbf{M}$} & \multirow[b]{2}{*}{ SD } & \multirow[b]{2}{*}{$\%$} \\
\hline & & 1 & 2 & 3 & 4 & 5 & & & \\
\hline 1 & God loves and cares for me & & & 0.9 & 12.0 & 87.1 & 4.863 & 0.369 & 97.3 \\
\hline 2 & $\begin{array}{l}\text { I feel that this life is a positive } \\
\text { experience }\end{array}$ & & 0.5 & 1.5 & 20.1 & 77.9 & 4.754 & 0.496 & 95.1 \\
\hline 3 & $\begin{array}{l}\text { I have a personal relationship with } \\
\text { Allah }\end{array}$ & 0.1 & & 3.0 & 24.3 & 72.6 & 4.693 & 0.537 & 93.9 \\
\hline 4 & $\begin{array}{l}\text { I feel that life is meaningful and a } \\
\text { rewarding experience }\end{array}$ & & & 2.0 & 29.6 & 68.4 & 4.664 & 0.513 & 93.3 \\
\hline 5 & $\begin{array}{l}\text { I feel that my life is moving in the } \\
\text { right direction to ensure my } \\
\text { welfare }\end{array}$ & & & 2.1 & 31.6 & 66.3 & 4.641 & 0.522 & 92.8 \\
\hline 6 & $\begin{array}{l}\text { I believe that Allah will take care of } \\
\text { my problems }\end{array}$ & & 0.4 & 0.8 & 29.5 & 69.4 & 4.679 & 0.506 & 93.6 \\
\hline 7 & I feel that I have a good future & & 0.5 & 2.6 & 35.0 & 61.9 & 4.583 & 0.571 & 91.7 \\
\hline 8 & $\begin{array}{l}\text { Relationship with Allah helps me } \\
\text { not to feel lonely }\end{array}$ & & 0.4 & 1.6 & 31.1 & 66.9 & 4.645 & 0.533 & 92.9 \\
\hline 9 & $\begin{array}{l}\text { I find it very meaningful when } \\
\text { communicating with Allah }\end{array}$ & & 0.4 & 2.4 & 30.3 & 67.0 & 4.639 & 0.549 & 92.8 \\
\hline 10 & $\begin{array}{l}\text { My relationship with Allah } \\
\text { contributes to my prosperity }\end{array}$ & & 0.4 & 1.8 & 31.0 & 66.9 & 4.644 & 0.536 & 92.9 \\
\hline 11 & $\begin{array}{c}\text { My life has a real purpose } \\
\text { Total }\end{array}$ & 0.1 & $\begin{array}{c}0.4 \\
0.27\end{array}$ & $\begin{array}{c}1.6 \\
\mathbf{1 . 3 4}\end{array}$ & $\begin{array}{c}29.8 \\
\mathbf{2 7 . 6 6}\end{array}$ & $\begin{array}{c}68.3 \\
\mathbf{7 0 . 2 4}\end{array}$ & $\begin{array}{l}4.659 \\
4.679\end{array}$ & $\begin{array}{l}0.529 \\
0.399\end{array}$ & $\begin{array}{l}93.2 \\
93.6\end{array}$ \\
\hline
\end{tabular}

*1 = strongly disagree $(1-20 \%), 2=$ disagree $(21-40 \%), 3=$ somewhat agree $(41-60 \%), 4$ = agree $(61-$ $80 \%), 5$ = strongly agree $(81-100 \%)$.

Between $21.0 \%$ and $37.6 \%$ of the respondents have a medium level of religiosity. This is arrived at by merging the "somewhat agree" and "agree" columns. They also believe in all the items but are not as confident as those in the "strongly agree" column. There were, though, a few dissenters of whom $0.1 \%$ strongly disagreed with only one statement: "I have a personal relationship with God". Moreover, within the same group, statements like "I feel that this life is a positive experience", "I believe that Allah will take care of my problems", "I feel that I have a good future", and "My life has a purpose that is real" also received the "disagree" response. It implies that they are not sure of their relationships with Allah at a personal level. However, their faith in Allah remains strong. This is evident from the empty cells under the "disagree" and "strongly disagree" columns for items "God loves and cares for me", "I feel that life is meaningful and a 
rewarding experience", and "I feel that my life is moving in the right direction to ensure my welfare". Overall, $70.2 \%$ of respondents have a high level of religiosity as measured in terms of their relationship with Allah. Respondents who "agree" or "somewhat agree" account for $27.7 \%$ and $1.3 \%$, respectively. At the lowest level are those in the "disagree" or "somewhat disagree" columns totalling only $0.1 \%$ and $0.3 \%$ respectively.

\section{The Importance of Prayer (Salat)}

To believe in God implies a belief in the rites and rituals enjoined by God. Thus, the respondents were asked about the importance of prayers (salat). As shown in Table 2, all the believers agreed in varying degrees to the importance of prayers. Only $0.1 \%$ of the respondents strongly disagreed with one item which says that prayer is a duty commanded by God. Between $70.1 \%$ and $85.6 \%$ of them strongly agreed with all the items. They believe that prayer is an obligation, that prayer can eliminate minor sins as well as keep one away from indulging in prohibited actions, and that those who pray will be rewarded and will be happy.

Conversely, those who do not pray will be punished. The respondents who are in the range between $14.0 \%$ and $29.9 \%$ on the importance of prayer may be categorized as having a medium level of religiosity. The difference in their beliefs about prayer is only a matter of degree. A remarkable aspect of the responses is regarding the item that asked if they know how to perform the prayer properly to which $70 \%$ agreed and 30\% agreed or somewhat agreed. This implies that these respondents may be in need of education and socialization in matters of prayers.

Table 2: The Importance of prayer (Salat)

\begin{tabular}{|c|c|c|c|c|c|c|c|c|}
\hline \multirow[t]{2}{*}{ No. } & \multirow[t]{2}{*}{ The Importance of Prayer (Salat) } & \multicolumn{4}{|c|}{ Level of Agreement* } & \multirow[b]{2}{*}{ M } & \multirow[b]{2}{*}{ SD } & \multirow[b]{2}{*}{$\%$} \\
\hline & & 1 & 23 & 4 & 5 & & & \\
\hline 1 & Prayer is a duty enjoined on the believers & 0.1 & 1.1 & 22.6 & 76.1 & 4.746 & 0.477 & 94.9 \\
\hline 2 & $\begin{array}{l}\text { Performing prayers can eliminate minor } \\
\text { sins }\end{array}$ & & 1.1 & 24.5 & 74.4 & 4.733 & 0.468 & 94.7 \\
\hline 3 & I know how to pray properly & & 3.8 & 26.1 & 70.1 & 4.664 & 0.546 & 93.3 \\
\hline 4 & $\begin{array}{l}\text { Allah will punish those who refuse to abide } \\
\text { by His commands }\end{array}$ & & 3.0 & 20.9 & 76.1 & 4.731 & 0.507 & 94.7 \\
\hline 5 & $\begin{array}{l}\text { Performing prayers can refrain one from } \\
\text { committing sins }\end{array}$ & & 1.0 & 22.0 & 77.0 & 4.760 & 0.450 & 95.2 \\
\hline 6 & $\begin{array}{l}\text { Allah will reward me for performing } \\
\text { prayers }\end{array}$ & & 0.4 & 18.5 & 81.1 & 4.808 & 0.404 & 96.2 \\
\hline 7 & $\begin{array}{l}\text { Those who perform prayers will get } \\
\text { happiness in this world }\end{array}$ & & 0.4 & 14.0 & 85.6 & 4.853 & 0.365 & 97.1 \\
\hline & Total & & & & & 4.756 & 0.385 & 95.1 \\
\hline
\end{tabular}

\section{Performance of Prayers}

To believe in the importance of prayers is one thing, but to pray as prescribed is something else. The Quran categorically states that prayers are prescribed for the believers at appointed times. The Quran also mentions that prayers protect the believers from indulging in prohibited activities. A person who remembers Allah constantly will attain salvation in this world and the hereafter. Allah in His infinite mercy has made His remembrance continuous by prescribing prayers five times a day. This was repeatedly emphasized by the Prophet and he warned that those who deliberately and intentionally neglect prayers are rebels. The questionnaire, therefore, was intended to ascertain the level of commitment in performing prayers. 
As shown in Table 3, five items refer specifically to the five obligatory prayers. Between $71 \%$ and $77 \%$ of the respondents performed prayers regularly. The frequency of the subh (morning) prayer was the least (71.3\%) among those who prayed regularly. This may be because the subh prayer is difficult to perform as the worshippers have to wake up early, which occasionally they may not have done. However, it is interesting to note the responses to item 6, which asks about the frequency of the Sunnah prayers before and after the obligatory prayers. Only 43.3\% strongly agreed with this item, which shows that the respondents do not take Sunnah prayers seriously since these prayers are not obligatory.

Some respondents $(40.3 \%)$ do not perform congregational prayers at home. This is expected since during the daytime, the believers may be working, and hence they may be praying outside the home. The percentage of the respondents who strongly agreed that they pray five times a day wherever they are is $63.8 \%$, while $53.5 \%$ said that they pray at the appointed times. Many of them (56.5\%) will not abandon the obligatory prayers because of their busy schedule, and $55.4 \%$ would even ask their fellow travellers to stop for prayers. To the question of whether they perform prayers properly, $66.4 \%$ of the respondents strongly agreed. In other words, it might be interpreted that although they pray, they are not sure if they perform it properly.

Between $0.3 \%$ and $0.9 \%$ of the respondents disagreed with the items on the frequency of praying. This may mean that they do not give much importance to the five daily prayers. Over $9 \%$ of respondents would not mind leaving the obligatory prayers because of their preoccupation with their daily activities. These respondents can be categorized as belonging to the low level of religiosity. The rest are in the medium religiosity category. They range from $22 \%$ to $28 \%$ with respect to the obligatory prayers and around $40 \%$ for the non-obligatory prayers.

Table 3: Performance of prayers (Salat)

\begin{tabular}{|c|c|c|c|c|c|c|c|c|c|}
\hline \multirow[t]{2}{*}{ No. } & \multirow[t]{2}{*}{ Performance of prayer (Salat) } & \multicolumn{5}{|c|}{ Level of Frequency* } & \multirow[b]{2}{*}{$\mathbf{M}$} & \multirow[b]{2}{*}{ SD } & \multirow[b]{2}{*}{$\%$} \\
\hline & & 1 & 2 & 3 & 4 & 5 & & & \\
\hline 1 & I perform Subh prayer frequently & & 0.8 & 3.5 & 24.5 & 71.3 & 4.663 & 0.582 & 93.3 \\
\hline 2 & I perform Zohor prayer frequently & & 0.9 & 3.3 & 22.4 & 73.5 & 4.685 & 0.5 & 93.7 \\
\hline 3 & I perform Asar prayer frequently & & 0.3 & 3.3 & 19.9 & 76.6 & 4.729 & 0.527 & 94.6 \\
\hline 4 & I perform Maghrib prayer frequently & & & 3.0 & 22.4 & 74.6 & 4.716 & 0.513 & 94.3 \\
\hline 5 & I perform Isha' prayer frequently & & 0.5 & 3.5 & 22.8 & 73.3 & 4.688 & 0.562 & 93.8 \\
\hline 6 & $\begin{array}{l}\text { I perform Sunnat prayers before and } \\
\text { after obligatory prayers }\end{array}$ & 1.8 & 7.4 & 20.1 & 27.5 & 43.3 & 4.031 & 1.042 & 80.6 \\
\hline 7 & $\begin{array}{l}\text { I often perform congregational prayers } \\
\text { at home }\end{array}$ & 5.1 & 12.8 & 20.9 & 21.0 & 40.3 & 3.785 & 1.240 & 75.7 \\
\hline 8 & I try to perform prayers properly & & 2.0 & 4.5 & 27.1 & 66.4 & 4.579 & 0.674 & 91.6 \\
\hline 9 & I pray five times a day wherever I am & 0.6 & 2.3 & 6.4 & 27.0 & 63.8 & 4.510 & 0.767 & 90.2 \\
\hline 10 & I perform obligatory prayers on time & 0.6 & 2.3 & 6.4 & 27.0 & 63.8 & 4.510 & 0.767 & 90.2 \\
\hline 11 & $\begin{array}{l}\text { I will not abandon obligatory prayers } \\
\text { when running out of time to carry out } \\
\text { daily tasks }\end{array}$ & 5.3 & 3.9 & 8.0 & 26.4 & 56.5 & 4.250 & 1.101 & 85.0 \\
\hline 12 & $\begin{array}{l}\text { I would invite those who travel with } \\
\text { me to stop for a moment to perform } \\
\text { prayers }\end{array}$ & 1.6 & 4.1 & 9.5 & 29.4 & 55.4 & 4.328 & 0.924 & 86.6 \\
\hline & Total & & & & & & 4.438 & 0.567 & 88.8 \\
\hline
\end{tabular}

*1 = never (1-20\%), 2 = seldom (21-40\%), $3=$ sometimes $(41-60 \%), 4=$ always $(61-80 \%), 5=$ every time $(81-100 \%)$.

\section{Factors Influencing Performance of Prayers}

People are the product of the socialization process they experience. Consequently, it is assumed that people pray because they have been socialized into praying by parents, friends and 
colleagues in the workplace. Table 4 contains seven items, six of which refer to one of the three socializing agents. One item refers to self as the motivating factor. Simply stated, this item says that people pray because they feel happy and calm after praying. This item scored the highest (63.4\%) among the strongly agreed responses. A majority of them (51.8\%) believe that they have been taught to pray by their parents. Teachers received $49.5 \%$ positive responses. Those who disagreed or strongly disagreed with these items range from $1.3 \%$ to $3.6 \%$.

The items in Table 6.4 require people to go back into their past and think of the influences they remember. Hence, it is probable that the respondents were not absolutely sure of the factors that influenced them to pray. This perhaps accounts for those who agreed somewhat or simply agreed. These medium level respondents range between 26\% (for self-satisfaction) and 51\% (for teachers). If the 'agree' and 'strongly agree' responses are merged then it can be seen that about $90 \%$ of them believe that they have been influenced by these factors in making them pray. Among those who disagreed with these items, they believe that neither parents nor friends have exerted any influence whatsoever in matters concerning prayers.

Table 4: Factors influencing the performance of prayer (Salat)

\begin{tabular}{|c|c|c|c|c|c|c|c|c|c|}
\hline \multirow[t]{2}{*}{ No. } & \multirow{2}{*}{$\begin{array}{l}\text { Factors that influence performing the } \\
\text { prayer (Salat) }\end{array}$} & \multicolumn{5}{|c|}{ Level of Agreement* } & \multirow[b]{2}{*}{ M } & \multirow[b]{2}{*}{ SD } & \multirow[b]{2}{*}{$\%$} \\
\hline & & 1 & 2 & 3 & 4 & 5 & & & \\
\hline 1 & I accompany a friend who prays regularly & 2.0 & 1.0 & 6.1 & 41.9 & 48.9 & 4.411 & 1.964 & 88.2 \\
\hline 2 & $\begin{array}{l}\text { Teachers help me a lot to improve my } \\
\text { prayer }\end{array}$ & 0.4 & 1.6 & 5.3 & 45.8 & 47.0 & 4.374 & 0.694 & 87.5 \\
\hline 3 & $\begin{array}{l}\text { My parents taught me to pray since } \\
\text { childhood }\end{array}$ & & 2.4 & 4.4 & 41.5 & 51.8 & 4.426 & 0.689 & 88.5 \\
\hline 4 & $\begin{array}{l}\text { Teachers often remind me to perform } \\
\text { prayers properly while doing daily tasks }\end{array}$ & 0.8 & 1.8 & 5.4 & 42.6 & 49.5 & 4.384 & 0.735 & 87.7 \\
\hline 5 & $\begin{array}{l}\text { Friends always invite me to perform } \\
\text { prayers either in the mosque or the hostel }\end{array}$ & 2.3 & 1.3 & 5.9 & 44.1 & 46.5 & 4.314 & 0.824 & 86.3 \\
\hline 6 & $\begin{array}{l}\text { My community carries out a lot of } \\
\text { activities that influence me to perform } \\
\text { prayers }\end{array}$ & 1.8 & 1.4 & 7.3 & 43.6 & 46.0 & 4.308 & 0.807 & 86.2 \\
\hline 7 & $\begin{array}{l}\text { I feel calm when praying } \\
\text { Total }\end{array}$ & 0.1 & 0.3 & 2.4 & 33.9 & 63.4 & $\begin{array}{l}4.601 \\
4.403\end{array}$ & $\begin{array}{l}0.564 \\
0.635\end{array}$ & $\begin{array}{r}92.0 \\
\mathbf{8 8 . 0}\end{array}$ \\
\hline
\end{tabular}

*1 = strongly disagree (1-20\%), 2 = disagree $(21-40 \%), 3=$ somewhat agree $(41-60 \%), 4$ = agree (61$80 \%), 5$ = strongly agree $(81-100 \%)$.

\section{Recitation of the Quran}

Performing prayers require reciting the Quran. It can, therefore, be assumed that those who pray regularly also know how to read the Quran. Believers also recite the Quran outside the prayers for additional rewards and self-satisfaction. Most believers recite the Quran in the morning, usually after the Subh prayer, before going to work; some prefer to read it between the Maghrib and Isha' prayers.

The respondents to the questionnaire also recite the Quran outside prayers as shown in Table 5. Interestingly, $58.6 \%$ strongly agreed, and $34.7 \%$ agreed that reading the Quran is important in their daily lives. Only $1.6 \%$ disagreed with this item. About $87 \%$ have completed reciting the Quran at least once as against 5.3\% who have not done so; $79 \%$ have recited the Quran completely several times while about 7\% have not; $75 \%$ of them make it a habit of completing the Quran once every year; 95\% believe that Quran recitation provides happiness to their souls and about $96 \%$ believe that Quran recitation helps improve moral standards; while $91 \%$ believe that reading the Quran is a way to get closer to Allah and to get to know the teachings of Islam. There are about $11 \%$ who do not try to read the Quran at least once a year. 
Among the respondents, 28.3\% "strongly agreed" that they recite the Quran every time after prayers, while $29.7 \%$ said they often read it. In other words, the majority of respondents do recite the Quran but not after every prayer or every day. Similarly, they may recite the Quran but not necessarily during their free time; instead, they recite it whenever they have the time to do so. The percentage of respondents trying to understand the contents of the Quran is $45.8 \%$ for those who strongly agreed and $39.8 \%$ for those who merely agreed.

Table 5: Practice of reciting the Quran

\begin{tabular}{|c|c|c|c|c|c|c|c|c|c|}
\hline \multirow[t]{2}{*}{ No. } & \multirow[t]{2}{*}{ Practice of reciting the Quran } & \multicolumn{5}{|c|}{ Level of Agreement* } & \multirow[b]{2}{*}{$\mathbf{M}$} & \multirow[b]{2}{*}{ SD } & \multirow[b]{2}{*}{$\%$} \\
\hline & & 1 & 2 & 3 & 4 & 5 & & & \\
\hline 1 & $\begin{array}{l}\text { I recite Al-Quran every time after } \\
\text { prayers }\end{array}$ & 1.4 & 5.3 & 18.8 & 46.3 & 28.3 & 3.949 & 0.896 & 79.0 \\
\hline 2 & I often read Al-Quran & 1.4 & 3.5 & 19.3 & 46.2 & 29.7 & 3.993 & 0.869 & 79.9 \\
\hline 3 & $\begin{array}{l}\text { I love to read the Quran during my } \\
\text { free time }\end{array}$ & 1.4 & 3.4 & 14.4 & 52.6 & 28.3 & 4.030 & 0.828 & 81.0 \\
\hline 4 & $\begin{array}{l}\text { I am trying to understand the } \\
\text { meanings of Al-Quranic verses that I } \\
\text { read }\end{array}$ & 1.0 & 1.8 & 11.8 & 39.8 & 45.8 & 4.275 & 0.813 & 86.0 \\
\hline 5 & $\begin{array}{l}\text { I take Al-Quran as a reference in my } \\
\text { daily life }\end{array}$ & 1.3 & 2.1 & 11.8 & 40.0 & 44.9 & 4.251 & 0.8376 & 85.0 \\
\hline 6 & $\begin{array}{l}\text { I have completed (khatam) Al-Quran } \\
\text { recital }\end{array}$ & 2.8 & 2.5 & 8.4 & 31.9 & 54.5 & 4.329 & 0.932 & 86.6 \\
\hline 7 & $\begin{array}{l}\text { I have completed reading Al-Quran } \\
\text { several times }\end{array}$ & 3.3 & 3.6 & 14.6 & 31.6 & 46.9 & 4.153 & 1.015 & 83.1 \\
\hline 8 & $\begin{array}{l}\text { I try to read the complete Quran at } \\
\text { least once a year }\end{array}$ & 4.9 & 6.3 & 13.6 & 26.9 & 48.4 & 4.076 & 1.142 & 81.5 \\
\hline 9 & $\begin{array}{l}\text { I realize the importance of reading the } \\
\text { Quran in daily lives }\end{array}$ & 0.3 & 1.3 & 5.3 & 34.7 & 58.6 & 4.500 & 0.679 & 90.0 \\
\hline 10 & When I read Al-Quran, I feel calm & 0.3 & 0.6 & 3.8 & 40.9 & 54.5 & 4.488 & 0.627 & 89.8 \\
\hline 11 & $\begin{array}{l}\text { Reading Al-Quran is a way to get } \\
\text { closer to Allah and the teachings of } \\
\text { Islam }\end{array}$ & 0.3 & 0.4 & 3.8 & 40.9 & 54.8 & 4.495 & 0.615 & 89.9 \\
\hline 12 & $\begin{array}{l}\text { I have to improve the quality of my Al- } \\
\text { Quran recitation from time to time }\end{array}$ & 0.1 & 0.6 & 4.4 & 39.2 & 55.6 & 4.496 & 0.625 & 89.9 \\
\hline 13 & $\begin{array}{l}\text { Recitation of Al-Quran can help form } \\
\text { high morals }\end{array}$ & 0.1 & 0.1 & 3.5 & 36.6 & 59.6 & 4.555 & 0.583 & 91.1 \\
\hline & Total & & & & & & 4.276 & 0.592 & 85.6 \\
\hline
\end{tabular}

*1 = strongly disagree $(1-20 \%), 2=$ disagree $(21-40 \%), 3=$ somewhat agree $(41-60 \%), 4=$ agree $(61-$ $80 \%), 5$ = strongly agree $(81-100 \%)$.

\section{Practicing Faith/Worship ('Ibadah)}

Islam is a practical religion. It is to be lived. The life of a believer is a life of continuous worship ('ibadah). Every action of a believer is considered to be an act of worship if it is done according to the dictates of Islam. Table 6 captures this dimension in the life of the respondents. It contains 25 items asking if the respondents believe in God, take the Prophet as a role model, pay zakah, greet fellow human beings, fast during the month of Ramadan, and ask for forgiveness for committing sins. Fasting and zakah are obligatory and hence, could have been treated separately in a separate table, but they are included in this table as they relate directly to other members of the society.

As shown in Table 6, all the respondents acknowledge the existence of Allah. There is not a single response in the "disagree" or "strongly disagree" column, and hence, there is no atheist in the sample. Likewise, all of the respondents can recite the shahadah (testimony of faith), which is required of all Muslims. Similarly, respondents are careful so that they do not indulge in 
activities forbidden in Islam. This is because they are aware that the angels are recording all their deeds. They also seek help from Allah whenever they are in trouble.

Responses to items "I acknowledge the existence of Allah", "I can recite Shahadah", "I am afraid to do things forbidden by Allah", "When in difficulties, I will pray to Allah", "I am always careful about my actions because I know the angels record all my deeds", "I always pray and hope for the mercy of Allah", "I always strive for success", "I always ask Allah to forgive my sins", "I will pray to Allah after every prayer", "I fast during Ramadan because it is a sin to ignore fasting", and "I feel calm when performing the obligatory prayers" in Table 6 are all positive but with varying levels. The rest of the items have some "disagree" responses. It is, therefore, instructive to look at those items that have returned the negative responses.

About $1.0 \%$ of the respondents disagreed to the item that states that "Prophet Muhammad is a role model in my life". How could a Muslim believing in Allah not take the Prophet as a role model? The answer was provided by a respondent during the interviews. In his words, "I believe that the Prophet is a role model. I would become an unbeliever if I did not believe this. However, in my daily life, I forget about my Prophet. I do not follow in his footsteps. I do what I like and not how the Prophet would have liked me to do. Do you understand what I am saying? This is my personal problem". They also strongly disagreed with the statement that "reading the history of the life of Muhammad will make us love him more". A similar percentage of the respondents disagreed with the statement "I am always wary of doing things contrary to Islamic law". This is again a factual statement and is a confession that they do things that are not sanctioned in Islam.

The most dissenting answers recorded were 4\%, which is for the item "I will ensure that I pay zakah (on property/income/plant)". It is to be noted that disagreeing with these statements does not mean that their faith in Islam is any less than others. They are perhaps very honest to confess that they do not fulfil their obligations. It could as well be that their income does not reach a level where paying zakah becomes obligatory. A similar argument could be made concerning those who 'somewhat agree' and 'agree' with all the statements. Taken together, they constitute about $30 \%$ of the total respondents. They are all Muslims, but they are not very particular in fulfilling their religious obligations.

Table 6: Practicing faith/worship ('ibadah)

\begin{tabular}{|c|c|c|c|c|c|c|c|c|c|}
\hline \multirow{2}{*}{ No. } & \multirow{2}{*}{ Practicing faith/worship (Ibadah) } & \multicolumn{5}{|c|}{ Level of Agreement } & \multirow[b]{2}{*}{$\mathbf{M}$} & \multirow[b]{2}{*}{ SD } & \multirow[b]{2}{*}{$\%$} \\
\hline & & 1 & 2 & 3 & 4 & 5 & & & \\
\hline 1 & I acknowledge the existence of Allah & & & 0.3 & 9.3 & 90.5 & 4.902 & 0.306 & 98.0 \\
\hline 2 & I can recite Shahadah & & & 0.1 & 11.5 & 88.3 & 4.882 & 0.326 & 97.6 \\
\hline 3 & $\begin{array}{l}\text { I am afraid to do things forbidden by } \\
\text { Allah }\end{array}$ & & & 1.6 & 13.0 & 85.3 & 4.837 & 0.411 & 96.7 \\
\hline 4 & When in difficulties, I will pray to Allah & & & 1.5 & 15.0 & 83.5 & 4.820 & 0.422 & 96.4 \\
\hline 5 & $\begin{array}{l}\text { I am always careful about my actions } \\
\text { because I know the angels record all my } \\
\text { deed }\end{array}$ & & & 2.6 & 16.8 & 80.6 & 4.779 & 0.474 & 95.6 \\
\hline 6 & $\begin{array}{l}\text { Prophet Muhammad SAW is a role model } \\
\text { in my life }\end{array}$ & & 1.0 & 2.4 & 17.4 & 79.2 & 4.748 & 0.545 & 94.9 \\
\hline 7 & $\begin{array}{l}\text { Reading the history of the life of } \\
\text { Muhammad SAW will make us love him } \\
\text { more }\end{array}$ & & 0.9 & 3.0 & 18.8 & 77.3 & 4.726 & 0.559 & 94.5 \\
\hline 8 & $\begin{array}{l}\text { I always pray and hope for the mercy of } \\
\text { Allah }\end{array}$ & & & 1.4 & 15.8 & 82.8 & 4.815 & 0.423 & 96.3 \\
\hline 9 & I always strive for success & & & 0.8 & 17.5 & 81.7 & 4.810 & 0.412 & 96.2 \\
\hline 10 & $\begin{array}{l}\text { I am always wary of doing things contrary } \\
\text { to Islamic law }\end{array}$ & & 0.1 & 1.4 & 21.1 & 77.4 & 4.758 & 0.468 & 95.2 \\
\hline 11 & I always ask Allah to forgive my sins & & & 0.4 & 17.5 & 82.1 & 4.817 & 0.397 & 96.3 \\
\hline
\end{tabular}




\begin{tabular}{|c|c|c|c|c|c|c|c|c|c|}
\hline 12 & I fast during Ramadan & & 0.1 & 0.1 & 18.3 & 81.5 & 4.811 & 0.405 & 96.2 \\
\hline 13 & $\begin{array}{l}\text { I never 'skip' fasting during Ramadan } \\
\text { without excuses }\end{array}$ & 0.8 & 0.3 & 3.8 & 16.5 & 78.7 & 4.722 & 0.618 & 94.4 \\
\hline 14 & I will ensure that I pay zakah fitrah & 1.3 & 0.9 & 1.5 & 17.3 & 79.1 & 4.721 & 0.660 & 94.4 \\
\hline 15 & $\begin{array}{l}\text { I will ensure that zakah on } \\
\text { property/income/agricultural products } \\
\text { are paid }\end{array}$ & 1.5 & 2.5 & 3.1 & 17.9 & 74.9 & 4.623 & 0.793 & 92.5 \\
\hline 16 & $\begin{array}{l}\text { I will take an obligatory bath after I am } \\
\text { cleansed of major impurities }\end{array}$ & 0.1 & & 2.6 & 15.0 & 82.2 & 4.792 & 0.482 & 95.8 \\
\hline 17 & I will pray to Allah after every prayer & & & 2.1 & 15.2 & 82.7 & 4.806 & 0.447 & 96.1 \\
\hline 18 & $\begin{array}{l}\text { I always do things recommended by the } \\
\text { Prophet to get a lot of rewards such as } \\
\text { prayer and fasting, alms giving, } \\
\text { constantly remembering God, reciting the } \\
\text { Quran, and the like }\end{array}$ & 0.3 & 1.4 & 4.1 & 21.2 & 73.1 & 4.654 & 0.650 & 93.1 \\
\hline 19 & I always ensure that I eat halal food & & 0.3 & 2.8 & 18.3 & 78.7 & 4.754 & 0.506 & 95.1 \\
\hline 20 & $\begin{array}{l}\text { I always cover my aurat (Islamically } \\
\text { dressed) as required wherever I am }\end{array}$ & 0.1 & 1.4 & 2.0 & 21.4 & 75.1 & 4.699 & 0.590 & 93.9 \\
\hline 21 & $\begin{array}{l}\text { I love watching television programme } \\
\text { wherein people are Islamically dressed }\end{array}$ & & 1.4 & 4.4 & 23.2 & 71.1 & 4.639 & 0.634 & 92.8 \\
\hline 22 & I will recite 'bismillah' before I eat & & 0.5 & 1.5 & 24.1 & 73.9 & 4.714 & 0.515 & 94.3 \\
\hline 23 & $\begin{array}{l}\text { I strive to learn the principles of Islamic } \\
\text { jurisprudence better }\end{array}$ & & 1.0 & 1.6 & 24.1 & 73.3 & 4.696 & 0.552 & 93.9 \\
\hline 24 & $\begin{array}{l}\text { I fast during Ramadan because it is a sin } \\
\text { to ignore fasting }\end{array}$ & & & 2.5 & 20.2 & 77.3 & 4.748 & 0.489 & 94.9 \\
\hline 25 & $\begin{array}{l}\text { I feel calm when performing the } \\
\text { obligatory prayers }\end{array}$ & & & 2.4 & 19.8 & 77.8 & 4.754 & 0.483 & 95.1 \\
\hline & Total & & & & & & 4.761 & 0.351 & 95.2 \\
\hline
\end{tabular}

*1 = strongly disagree (1-20\%), $2=$ disagree $(21-40 \%), 3=$ somewhat agree $(41-60 \%), 4$ = agree (61$80 \%), 5$ = strongly agree $(81-100 \%)$.

\section{Moral Behavior}

A believer makes use of the Quranic text wherein they believe God has set forth (among other things) a moral vision. He commands certain actions and forbids others. He praises certain attitudes and discourages others. Many believers use their intellect and reason to discern basic moral truths set forth by God based on what He has created and the intrinsic meaning He has given to His creation. The Quran provides several values like al-`adl (justice), ihsan (kindness par excellence), amanah (trust), infaq (spending to meet social obligations), and sabr (patience). The negative values that should be avoided by Muslims include zulm (tyranny), bukhl (miserliness), hirs (greed), ihtikar (hoarding of wealth) and israf (extravagance). A believer is a man of character and is noted for honesty, ethics, and charity. A lack of character is a moral deficiency, and persons lacking character tend to behave dishonestly, unethically, and uncharitably.

Items in Table 7 are related to the character or moral behavior of the respondents. Interestingly, items that state "I am always polite to my parents", "I love decent appearance", and "If my friend borrows money from me, I will ask him to pay only the amount borrowed" elicited no "disagree" or "strongly disagree" responses. All the three items are clearly enjoined in the Quran, and they form a part of the Malay culture. About 74\% strongly agreed with the statement that they seek the pleasure of Allah by being kind to their parents. Almost the same percentage of the respondents greets their fellow believers, help those in need, refrain from offending others, seek forgiveness for any wrong doing, and speak the truth.

Respondents agreeing with those items stating that they refer to the Internet to get information about Islam or they refer to parents and/or teachers or other knowledgeable people about the validity and accuracy of information on the Internet about Islam range from $45 \%$ to 
$50 \%$. Those who disagreed with these items range from $22 \%$ to $26 \%$. In other words, when it comes to the Internet, they do not feel the necessity of referring the matter to others including parents and teachers.

The majority of respondents have acted positively towards the practice of morality, and they believe that morality aspects are important to them. This belief has a positive influence in their lives. Because of this belief, they feel that their life is significant, they have a purpose in life, and that Islam provides good guidelines for achieving their mission in life; hence, they are confident about their future.

Table 7: Moral behavior

\begin{tabular}{|c|c|c|c|c|c|c|c|c|c|}
\hline \multirow[t]{2}{*}{ No. } & \multirow[t]{2}{*}{ Practice of morality } & \multicolumn{5}{|c|}{ Level of Agreement* } & \multirow[b]{2}{*}{$\mathbf{M}$} & \multirow[b]{2}{*}{ SD } & \multirow[b]{2}{*}{$\%$} \\
\hline & & 1 & 2 & 3 & 4 & 5 & & & \\
\hline 1 & $\begin{array}{l}\text { I seek the pleasure of Allah through } \\
\text { serving my parents and making them } \\
\text { happy }\end{array}$ & 0.1 & & 2.1 & 24.1 & 73.7 & & 0.513 & 94.2 \\
\hline 2 & $\begin{array}{l}\text { Whenever I hear someone invoke } \\
\text { blessings on the Prophet, I would } \\
\text { immediately answer with a similar } \\
\text { invocation }\end{array}$ & 0.4 & 0.6 & 2.6 & 24.1 & 72.3 & 4.673 & 0.597 & 93.5 \\
\hline 3 & I am always polite to my parents & & & 2.8 & 26.8 & 70.4 & 4.677 & 0.524 & 93.5 \\
\hline 4 & $\begin{array}{l}\text { I always greet (give salam) whenever I } \\
\text { meet a fellow Muslim }\end{array}$ & 1.6 & 1 & 5.5 & 23.3 & 68.5 & 4.561 & 0.783 & 91.2 \\
\hline 5 & I always help those who are in trouble & & 0.8 & 5.4 & 25.7 & 68.1 & 4.612 & 0.625 & 92.2 \\
\hline 6 & $\begin{array}{l}\text { I always behave properly and refrain } \\
\text { from offending others }\end{array}$ & & 0.9 & 4.3 & 24.7 & 70.1 & 4.641 & 0.607 & 92.8 \\
\hline 7 & $\begin{array}{l}\text { I sincerely accept others' reprimand to } \\
\text { correct my mistakes }\end{array}$ & & 0.9 & 4.6 & 23.1 & 71.4 & 4.650 & 0.611 & 93.0 \\
\hline 8 & $\begin{array}{l}\text { I always exercise patience in an } \\
\text { unpleasant situation }\end{array}$ & 0.5 & 0.6 & 5.4 & 26.5 & 67 & 4.589 & 0.670 & 91.8 \\
\hline 9 & I love decent appearance & & & 4.3 & 25 & 70.8 & 4.665 & 0.555 & 93.3 \\
\hline 10 & $\begin{array}{l}\text { When I help someone, I do not expect } \\
\text { any reward (except from Allah) }\end{array}$ & & 0.8 & 4.3 & 23.6 & 71.4 & 4.656 & 0.597 & 93.1 \\
\hline 11 & $\begin{array}{l}\text { I ask for permission before borrowing } \\
\text { other people's things. }\end{array}$ & & 0.6 & 4.1 & 25.7 & 69.5 & 4.641 & 0.592 & 92.8 \\
\hline 12 & $\begin{array}{l}\text { If my friend borrows money from me, I } \\
\text { ask him to pay only the amount } \\
\text { borrowed }\end{array}$ & & & 4.9 & 23.3 & 71.8 & 4.669 & 0.566 & 93.4 \\
\hline 13 & $\begin{array}{l}\text { I immediately apologize for any } \\
\text { wrongdoing }\end{array}$ & & 1.5 & 5.5 & 24.7 & 68.3 & 4.598 & 0.664 & 92.0 \\
\hline 14 & I always speak the truth & 0.6 & 1.4 & 8.3 & 23.1 & 66.7 & 4.538 & 0.757 & 90.8 \\
\hline 15 & $\begin{array}{l}\text { I often refer to the Internet for questions } \\
\text { / issues and matters pertaining to Islam }\end{array}$ & 26.3 & 4.6 & 7 & 17.2 & 44.9 & 3.496 & 1.680 & 69.9 \\
\hline 16 & $\begin{array}{l}\text { I will refer/review with my parents } \\
\text { about the validity and accuracy of the } \\
\text { information I received through the } \\
\text { Internet about Islam }\end{array}$ & 26.3 & 5.1 & 7.1 & 16 & 45.4 & 3.490 & 1.686 & 69.8 \\
\hline 17 & $\begin{array}{l}\text { I will refer / review with teachers and } \\
\text { persons knowledgeable about the } \\
\text { validity and accuracy of the information } \\
\text { I received through the Internet about } \\
\text { Islam }\end{array}$ & 22.4 & 4 & 6.5 & 16.3 & 50.8 & 3.689 & 1.631 & 73.8 \\
\hline 18 & $\begin{array}{l}\text { I seek Allah's blessing by treating other } \\
\text { humans with kindness }\end{array}$ & 7 & 0.8 & 3.1 & 22.2 & 66.9 & 4.412 & 1.093 & 88.2 \\
\hline
\end{tabular}




\begin{tabular}{|c|c|c|c|c|c|c|c|c|c|}
\hline 19 & $\begin{array}{l}\text { I love to see men and women maintain } \\
\text { limits of their social boundaries } \\
\text { according to Islamic manner }\end{array}$ & 9.5 & 0.1 & 3.6 & 17.7 & 69 & 4.366 & 1.207 & 87.3 \\
\hline
\end{tabular}

$*_{1}$ = strongly disagree $(1-20 \%), 2=$ disagree $(21-40 \%), 3=$ somewhat agree $(41-60 \%), 4$ = agree $(61$ $80 \%), 5$ = strongly agree $(81-100 \%)$.

\section{Reference Institutions/Persons When Facing Problems}

The questionnaire contained items asking respondents about institutions or persons they would refer to when they face problems in their lives. As shown in Table 8.1, there are 14 institutions/persons, and they were given the option to choose as many as they prefer. Half of the respondents $(50.9 \%)$ chose husband/wife, and 35 to $38 \%$ chose siblings, ustadz/ustadzah, and friends to refer to when facing problems or issues. Very few respondents chose government bodies $(8.5 \%)$ or non-governmental organizations (NGOs) $(5.4 \%)$ as their reference points. Simply stated, respondents prefer family members and relatives to talk about their problems. Teachers and friends come next in importance. Moreover, they are confident that the closest individuals are most caring and understanding.

Table 8.1: Reference institutions/persons when facing problems

\begin{tabular}{lcc}
\hline \multicolumn{1}{c}{ Reference institutions/persons $(\boldsymbol{N}=\mathbf{8 0 0})$} & Frequency* & Percentage \\
\hline Husband/wife & 407 & 50.9 \\
Siblings & 304 & 38 \\
Ustadz/Ustadzah & 286 & 35.8 \\
Friends & 286 & 35.8 \\
Relatives & 225 & 28.1 \\
Parents & 224 & 28 \\
Committee member Prayer/Mosque & 216 & 27 \\
Books/Kitab & 172 & 21.5 \\
Neighbor & 132 & 16.5 \\
Teacher & 123 & 15.4 \\
Internet, social network, etc. & 120 & 15 \\
Does not refer to anyone & 91 & 11.4 \\
Government bodies & 68 & 8.5 \\
NGOs & 43 & 5.4 \\
\hline
\end{tabular}

However, when asked whom they would refer to in cases involving religious matters, $66.5 \%$ chose teachers, followed by $44.8 \%$ who would refer to prayer leaders or those in charge of mosques, while $39.3 \%$ would refer to books to seek answers to religious problems/issues. Between $30 \%$ and $37 \%$ of the respondents would refer to their spouses, electronic media, friends, and those attending religious classes (Table 8.2).

Table 8.2: Reference institutions/persons when searching for information on religion

\begin{tabular}{lcc}
\hline \multicolumn{1}{c}{ Reference institutions/persons } & Frequency & Percentage \\
\hline Ustadz/Ustadzah & 532 & 66.5 \\
Member Prayer/Mosque & 438 & 44.8 \\
Book/Al-Kitab/Magazine/Newspaper & 314 & 39.3 \\
Husband/wife & 296 & 37.0 \\
Electronic Media (TV, Radio) & 290 & 36.3 \\
Friends & 281 & 35.1 \\
Attend courses & 242 & 30.3 \\
Parents & 230 & 28.8 \\
\hline
\end{tabular}




\begin{tabular}{lcc}
\hline Internet, social network, etc. & 217 & 27.1 \\
Teacher & 216 & 27.0 \\
Neighbor & 216 & 15.8 \\
Siblings & 198 & 24.8 \\
Relatives & 187 & 23.4 \\
Government bodies & 87 & 10.9 \\
NGOs & 63 & 7.9 \\
Does not refer to anyone & 30 & 3.8 \\
\hline
\end{tabular}

\section{Explaining Religiosity}

Having described the level of religiosity among respondents, it is instructive to analyze the data further to obtain the characteristics of respondents across various dimensions including locality, gender, age, marital status, and education (Table 9).

Of all the variables, only locality seems to have a significant relationship with religiosity. Rural residents scored consistently high on all items as compared to those who live in urban areas. This is particularly revealing in their moral behavior wherein the rural residents reported high $(M=4.544, S D=0.522)$ as compared to the urban residents $(M=4.334, S D=0.579)$. Equally prominent is the response to the item referring to relationship with Allah. Those living in the rural areas $(M=4.720, S D=0.387)$ reportedly have a better relationship with Allah than those who live in the urban areas $(M=4.634, S D=0.410)$.

In terms of gender, there are no significant differences on any measure of religiosity except on their relationship with Allah. Female respondents are more positive about their relationship with Allah $(M=4.721, S D=0.383)$ as compared to their male counterparts $(M=$ $4.642, S D=0.412$ ) with other statistics $t=-2.817$ and $p=0.005$.

In terms of Quranic recitation, the older group (61 and above) performed better than those in the below 40 age group $(F=5.046, p=.007)$. Similarly, for moral behavior, the older respondents performed better than those in the below 60 age groups. In other words, the elderly group has a better relationship with Allah, believe in the importance of salat and perform it regularly, and practice worship ('ibadah) better than the other two groups.

In terms of marital status, no significant differences were found among the single, married, and divorced groups. There is a slight difference in terms of reciting the Quran wherein divorcees recite the Quran more than the single and the married groups.

Respondents were divided into three categories for education levels: primary school, secondary school, and tertiary education. Results indicate no significant differences among respondents. In terms of moral behavior, respondents with tertiary education $(M=4.455, S D=$ 0.550 ) performed slightly better than the other two groups, namely those with primary school education $(M=4.194, S D=0.546)$ and secondary school education $(M=4.409, S D=0.597)$, yet their differences are not significant.

Table 9: Religiosity by demographic characteristics of the respondents

\begin{tabular}{|c|c|c|c|c|c|c|c|}
\hline Variable & $\begin{array}{c}\text { Measur } \\
\text { e }\end{array}$ & $\begin{array}{l}\text { Relationshi } \\
\text { p with Allah }\end{array}$ & $\begin{array}{c}\text { Worshi } \\
\text { p }\end{array}$ & $\begin{array}{l}\text { Importanc } \\
\text { e of Prayer }\end{array}$ & $\begin{array}{c}\text { Performin } \\
\text { g Prayers }\end{array}$ & $\begin{array}{l}\text { Recitin } \\
\text { g the } \\
\text { Qu'ran }\end{array}$ & $\begin{array}{c}\text { Moral } \\
\text { Behavio } \\
\text { r }\end{array}$ \\
\hline \multicolumn{8}{|l|}{ Locality: } \\
\hline \multirow[t]{3}{*}{ Rural } & $n$ & 400 & 400 & 400 & 400 & 398 & 400 \\
\hline & Mean & 4.720 & 4.782 & 4.780 & 4.492 & 4.286 & 4.544 \\
\hline & $S D$ & 0.387 & 0.311 & 0.361 & 0.499 & 0.631 & 0.522 \\
\hline \multirow[t]{4}{*}{ Urban } & $n$ & 400 & 397 & 400 & 400 & 398 & 396 \\
\hline & Mean & 4.634 & 4.735 & 4.733 & 4.384 & 4.266 & 4.334 \\
\hline & $S D$ & 0.410 & 0.390 & 0.408 & 0.623 & 0.551 & 0.579 \\
\hline & $t$ & 2.959 & 1.882 & 1.744 & 2.704 & 0.470 & -5.365 \\
\hline
\end{tabular}




\begin{tabular}{|c|c|c|c|c|c|c|c|}
\hline & $p$ & .003 & .060 & .082 & .007 & .639 & .000 \\
\hline \multirow{4}{*}{$\begin{array}{l}\text { Gender: } \\
\text { Male }\end{array}$} & & & & & & & \\
\hline & $n$ & 436 & 435 & 436 & 436 & 436 & 434 \\
\hline & Mean & 4.642 & 4.750 & 4.736 & 4.436 & 4.272 & 4.432 \\
\hline & $S D$ & 0.412 & 0.375 & 0.396 & 0.596 & 0.599 & 0.575 \\
\hline \multirow[t]{5}{*}{ Female } & $n$ & 364 & 362 & 364 & 364 & 360 & 362 \\
\hline & Mean & 4.721 & 4.771 & 4.780 & 4.441 & 4.281 & 4.446 \\
\hline & $S D$ & 0.383 & 0.325 & 0.373 & 0.531 & 0.584 & 0.543 \\
\hline & $t$ & -2.817 & -0.854 & -1.607 & -0.139 & -0.198 & -0.357 \\
\hline & $p$ & .005 & .393 & .108 & .889 & .843 & .721 \\
\hline \multicolumn{8}{|l|}{$\begin{array}{l}\text { Age } \\
\text { (years) }\end{array}$} \\
\hline \multirow[t]{3}{*}{$<40$} & $n$ & 223 & 220 & 223 & 223 & 221 & 220 \\
\hline & Mean & 4.680 & 4.749 & 4.763 & 4.384 & 4.197 & 4.444 \\
\hline & $S D$ & 0.436 & 0.023 & 0.026 & 0.042 & 0.044 & 0.568 \\
\hline \multirow[t]{3}{*}{$41-60$} & $n$ & 398 & 398 & 398 & 398 & 396 & 397 \\
\hline & Mean & 4.666 & 4.748 & 4.745 & 4.434 & 4.271 & 4.409 \\
\hline & $S D$ & 0.389 & 0.018 & 0.020 & 0.028 & 0.030 & 0.571 \\
\hline \multirow[t]{6}{*}{$61>$} & $n$ & 179 & 179 & 179 & 179 & 179 & 179 \\
\hline & Mean & 4.703 & 4.796 & 4.774 & 4.515 & 4.385 & 4.497 \\
\hline & $S D$ & 0.380 & 0.025 & 0.028 & 0.036 & 0.036 & 0.525 \\
\hline & $F$ & 0.539 & 1.307 & 0.395 & 2.675 & 5.046 & 1.544 \\
\hline & $d f$ & 2,797 & 2,794 & 2,797 & 2,797 & 2,793 & 2,793 \\
\hline & $p$ & .584 & .271 & .674 & .070 & .007 & .214 \\
\hline \multicolumn{8}{|l|}{$\begin{array}{l}\text { Marital } \\
\text { Status: }\end{array}$} \\
\hline \multirow[t]{3}{*}{ Single } & $n$ & 95 & 95 & 95 & 95 & 95 & 95 \\
\hline & Mean & 4.672 & 4.723 & 4.759 & 4.380 & 4.185 & 4.462 \\
\hline & $S D$ & 0.389 & 0.359 & 0.384 & 0.628 & 0.654 & 0.594 \\
\hline \multirow[t]{3}{*}{ Married } & $n$ & 630 & 627 & 63 & 630 & 626 & 626 \\
\hline & Mean & 4.675 & 4.763 & 4.759 & 4.443 & 4.294 & 4.428 \\
\hline & $S D$ & 0.407 & 0.357 & 0.384 & 0.571 & 0.589 & 0.565 \\
\hline \multirow[t]{6}{*}{ Divorced } & $n$ & 75 & 75 & 75 & 75 & 75 & 75 \\
\hline & Mean & 4.719 & 4.772 & 4.28 & 4.477 & 4.244 & 4.493 \\
\hline & $S D$ & 0.361 & 0.312 & 0.405 & 0.439 & 0.529 & 0.475 \\
\hline & $F$ & 0.424 & 0.571 & 0.228 & 0.695 & 1.507 & 0.546 \\
\hline & $d f$ & 2,797 & 2,794 & 2,797 & 2,797 & 2,793 & 2,793 \\
\hline & $p$ & .655 & .565 & .797 & .499 & .222 & .579 \\
\hline \multicolumn{8}{|l|}{ Education } \\
\hline \multirow{4}{*}{$\begin{array}{l}\text { : } \\
\text { Primary } \\
\text { school }\end{array}$} & & & & & & & \\
\hline & $n$ & 25 & 25 & 25 & 25 & 25 & 25 \\
\hline & Mean & 4.622 & 4.632 & 4.634 & 4.250 & 4.166 & 4.194 \\
\hline & $S D$ & 0.445 & 0.430 & 0.543 & 0.553 & 0.557 & 0.546 \\
\hline \multirow{3}{*}{$\begin{array}{l}\text { Secondary } \\
\text { School }\end{array}$} & $n$ & 149 & 149 & 149 & 149 & 149 & 149 \\
\hline & Mean & 4.686 & 4.777 & 4.769 & 4.492 & 4.272 & 4.409 \\
\hline & $S D$ & 0.394 & 0.343 & 0.353 & 0.552 & 0.608 & 0.597 \\
\hline \multirow[t]{6}{*}{ Tertiary } & $n$ & 629 & 623 & 626 & 626 & 622 & 622 \\
\hline & Mean & 4.679 & 4.760 & 4.758 & 4.433 & 4.282 & 4.455 \\
\hline & $S D$ & 0.401 & 0.351 & 0.386 & 0.570 & 0.590 & 0.550 \\
\hline & $F$ & 0.274 & 1.821 & 1.338 & 2.071 & 0.463 & 2.877 \\
\hline & $d f$ & 2,797 & 2,794 & 2,797 & 2,797 & 2,793 & 2,793 \\
\hline & $p$ & .760 & .163 & .263 & .127 & .629 & .057 \\
\hline
\end{tabular}


Scholars agree that humans have a basic need to connect to a transcendent universe. Consequently, it is expected that religious beliefs and practices would be equally distributed in the population. Surveys, however, consistently find variations among population groups in different countries in the prevalence of religious beliefs and practices (such as belief in God and frequency of prayers) and measures of religiosity (such as frequency of religious attendance or religious identity). How prevalent is this religious belief among the Malays who by definition are Muslims? For this, it is important to monitor religious beliefs and practices since research from developmental science, sociology, and character education has found that they are positively related to identity and moral development, purpose and goal attainment, emotion and attention regulation, life satisfaction, and happiness.

This study used data from a survey to describe current patterns of religiosity among the Malays in Malaysia. A pattern noted is the clear imprint of religion on the beliefs of the Malays such that the respondents scored high on questions of religiosity. They said that religion is essential in their lives and hence they attach importance to prayers and pray as and when prescribed. They fast regularly and pay zakah. There is no atheist in the sample studied. If secularism is defined as confining religion to private affairs, then none of the Malays could be termed secular. They often feel a deep connection with God, and they think about the meaning and purpose of life lived in obedience to the dictates of Islam. Most of the Malays are influenced by their parents, teachers, and the community as a whole to lead a religious life. Indeed, the respondents varied in their responses, but the variation is in degree rather than in kind.

However, most of the Malays place more importance on obligatory prayers and less to supererogatory prayers. Most of them agreed that they do hold the Prophet (SAW) as a role model. Contrary to expectations, some Malays also disclosed information regarding unacceptable religious behavior. They admitted that they are not strong believers and do not perform the obligatory duties of Muslims such as the five daily prayers, fasting in the month of Ramadan, and paying zakah. Nevertheless, looking at the responses to items on the religiosity scales, it was found that overall, about $67 \%$ belong to a high level of religiosity; about $30 \%$ belong to the medium category; and only about $3.0 \%$ fall in the low level of religiosity.

The responses to the religiosity scales were also cross-tabulated to find the relationship between religiosity and age, education, gender, and marital status; and with locality measured in terms of urban and rural differences. These tables did not reveal any significant relationship between religiosity and other variables with the only exception of locality. The rural population consistently scored high on all measures of religiosity.

Apparently, religiosity plays an essential role in promoting and protecting morality in the society. This study found that the Malays are polite in their behavior to their parents and they try to help others, refrain from taking interests on loans to friends, and the like. When it comes to the Internet, they tend to rely upon themselves more than upon their parents or others to verify the accuracy of information on matters pertaining to Islam collected from the Internet. Islam seems to influence all aspects of the behavior of the Malays in Malaysia. Most of them would abide by most of the dictates of their religion in their dealings with others.

This study on the religiosity of the Malays, while limited by a lack of comparability of the various data sources and definitions, suggests consistent patterns that beg for further study and verification. With further conceptual and measurement work, eventually, this important domain of Malay well-being can be well measured.

\section{Acknowledgement}

The authors gratefully acknowledge the financial support received under the IIUM Presidential Research grant. 


\section{References}

Abdullah, T., \& Siddique, S. (ed.). 1986. Islam and Society in Southeast Asia. Singapore: Institute of Southeast Asian Studies.

Allport, G. W., \& Ross, J. M. 1967. Personal religious orientation and prejudice. Journal of Personality and Social Psychology 5(4): 432-443.

Azzi, C. \& Ehrenberg, R. G. 1975. Household allocation of time and church attendance. Journal of Political Economy 83(1): 27-56.

Bruce, S. 1998. The charismatic movement and the secularisation thesis. Religion 28(3): 223-232.

Bruce, S. 2000. The supply-side model of religion: The Nordic and Baltic States. Journal for the Scientific Study of Religion 39(1): 32-46.

Bruce, S. 2002. God is dead: Secularization in the West. Oxford: Blackwell Publishing Ltd.

Caird, D. 1987. Religiosity and personality: Are mystical introverted, neurotic, or psychotic. British Journal of Social Psychology 26(2): 345-346.

Demerath, N. J. 2000. The rise of "cultural religion" in European Christianity: Learning from Poland, Northern Ireland, and Sweden. Social Compass 47(1): 127-139.

SHofstede, G. 1980. Culture Consequences: International Differences in Work-Related Values. London: Sage Publications.

Hunt, S. D. \& Vitell, S. J. 2006. A general theory of marketing ethics: A revision and three questions. Journal of Macromarketing 26(2): 143-153.

Kliever, L. D. 1979. Polysymbolism and modern religiosity. Journal of Religion 59(2): 169-194.

Lechner, F. J. 1996. Secularization in the Netherlands?. Journal for the Scientific Study of Religion. 35(3): 252-264.

Monaghan, R. R. 1967. Three faces of the true believer: Motivations for attending a fundamentalist church. Journal for the Scientific Study of Religion 6(2): 236-245.

Mookherjee, H. N. 1993. Effects of religiosity and selected variables on the perception of wellbeing. The Journal of Social Psychology 134(3): 403-405.

Sadler, W. 1970. Personality and Religion: The Role of Religion in Personality Development. London: SCM Press Ltd.

Saeed, M., Ahmed, Z. U., \& Mukhtar, S. M. 2001. International marketing ethics from an Islamic perspective: A value-maximization approach. Journal of Business Ethics. 32(2): 127-142.

Sood, J. \& Nasu, Y. 1995. Religiosity and nationality an exploratory study of their effect on consumer behavior in Japan and the United States. Journal of Business Research 34(1): 19. 